\title{
Integrative Taxonomy Reveals That the Marine Brachyuran Crab Pyromaia tuberculata (Lockington, 1877) Reached Eastern Atlantic
}

\author{
Jorge Lobo-Arteaga ${ }^{1,2, *(\mathbb{D})}$, Miriam Tuaty-Guerra ${ }^{1,3}(\mathbb{D})$ and Maria José Gaudêncio ${ }^{1}$ \\ 1 Instituto Português do Mar e da Atmosfera, I.P. (IPMA), Av. Alfredo Magalhães Ramalho, 6, \\ 1495-165 Algés, Portugal; mguerra@ipma.pt (M.T.-G.); mgaudencio@ipma.pt (M.J.G.) \\ 2 Centro de Ciências do Mar e do Ambiente (MARE), Universidade Nova de Lisboa, Campus de Caparica, \\ 2829-516 Caparica, Portugal \\ 3 Centro Interdisciplinar de Investigação Marinha e Ambiental (CIIMAR), Universidade do Porto, \\ Terminal de Cruzeiros do Porto de Leixões, 4450-208 Matosinhos, Portugal \\ * Correspondence: jorge.arteaga@ipma.pt
}

check for updates

Citation: Lobo-Arteaga, J.; Tuaty-Guerra, M.; Gaudêncio, M.J. Integrative Taxonomy Reveals That the Marine Brachyuran Crab Pyromaia tuberculata (Lockington, 1877) Reached Eastern Atlantic. Diversity 2021, 13, 225. https://doi.org/ $10.3390 / \mathrm{d} 13060225$

Academic Editors: Manuel Elias-Gutierrez and Eric Buffetaut

Received: 4 May 2021

Accepted: 19 May 2021

Published: 23 May 2021

Publisher's Note: MDPI stays neutral with regard to jurisdictional claims in published maps and institutional affiliations.

Copyright: (c) 2021 by the authors. Licensee MDPI, Basel, Switzerland. This article is an open access article distributed under the terms and conditions of the Creative Commons Attribution (CC BY) license (https:// creativecommons.org/licenses/by/ $4.0 /)$.

\begin{abstract}
Pyromaia tuberculata is native to the north-eastern Pacific Ocean and currently established in distant regions in the Pacific Ocean and southwest Atlantic. Outside its native range, this species has become established in organically polluted enclosed waters, such as bays. The Tagus estuary, with a broad shallow bay, is one of the largest estuaries in the west coast of Europe, located in western mainland Portugal, bordering the city of Lisbon. In this study, sediment samples were collected in the estuary between 2016 and 2017. Several adult specimens of P. tuberculata, including one ovigerous female, were morphologically and genetically identified, resulting in accurate identification of the species. The constant presence of adults over a 16-month sampling period suggests that the species has become established in the Tagus estuary. Moreover, their short life cycle, which allows for the production of at least two generations per year, with females reaching maturity within six months after settlement, favours population establishment. Despite being referred to as invasive, there are no records of adverse effects of $P$. tuberculata to the environment and socio-economy in regions outside its native range. However, due to its expanding ability, its inclusion in European monitoring programmes would indeed be desirable.
\end{abstract}

Keywords: Decapoda; DNA barcoding; European marine waters; larval stage; macrobenthos; new record; non-indigenous species

\section{Introduction}

Brachyuran and crab-like anomuran decapods are worldwide-spread taxa and therefore easily established beyond their native regions. Brockerhoff and McLay [1] reported that 48 of the 73 (i.e., 66\%) worldwide non-indigenous species of brachyuran and crablike anomuran decapods became established. Pyromaia tuberculata (Lockington, 1877) is a brachyuran decapod, belonging to the family Inachoididae. This species is native to the north-eastern Pacific Ocean, from the Gulf of California to the Panama Canal [2], and lives under rocks, among sponges and seaweed, on wharf piles, and on sand and mud, from the intertidal zone to $650 \mathrm{~m}$ depth [1]. P. tuberculata is widely distributed and already established in distant regions in the Pacific Ocean, where the first record out of its native region was in Japan, before 1970 [3]. Approximately two decades after, it was found in Brazil, southwest Atlantic Ocean. However, its occurrence was considered as a natural distribution pattern [4]. More recently, Tavares and Mendonça [5] recognized it as a non-indigenous species in the southwest Atlantic Ocean, with records in Brazil and Argentina (Figure 1). Out of its native distribution range, $P$. tuberculata has been reported in organically polluted ecosystems, such as Tokyo Bay (Japan) and Guanabara Bay (Brazil) [5]. 


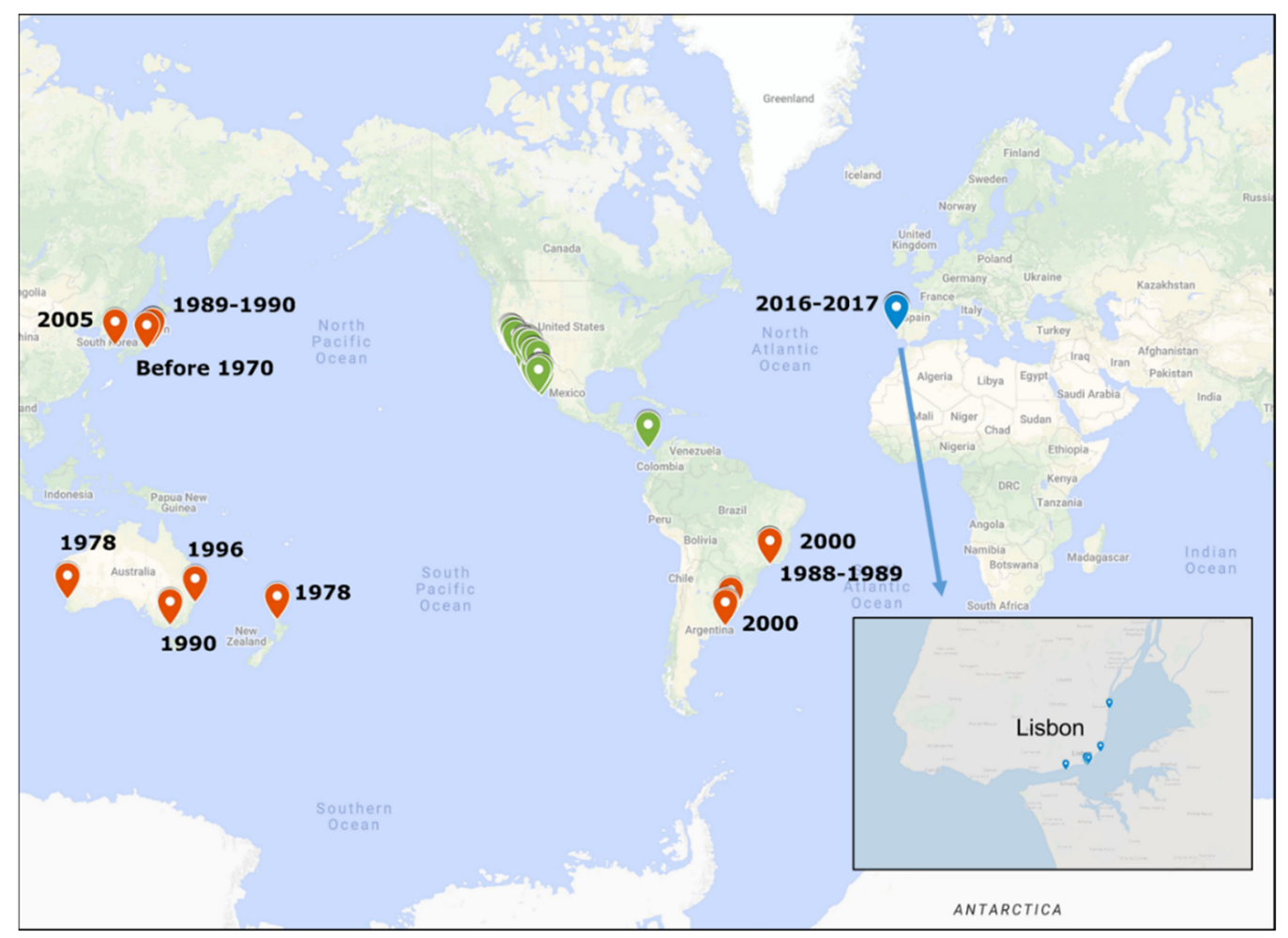

Figure 1. Location and date of collection of P. tuberculata specimens. Green pinpoints: native locations; orange pinpoint: non-native locations; blue pinpoints: new records. Available geographical coordinates were used for the United States, Mexico, and Panama [2], Japan and South Korea [3,6-8], Australia and New Zealand [9-12], and Argentina and Brazil [13,14]. The map was created using Google Map Maker (https:/ /www.google.com/maps/d/) (1 March 2020) and edited with GNU Image Manipulation Program (GIMP) 2.10.8.

Due to the complexity of taxonomy, experts generally work with local or regional dichotomous keys for identifying species. Identifying non-indigenous species which are not expected to occur in a specific locality is not an easy task. In those situations, genetic tools are very useful and can help to identify species faster, easier and more accurately. The barcode region of the mtDNA gene cytochrome c oxidase I (COI-5P) is broadly used to identify and discriminate crustacean species [15-17], including decapods [18]. In this study, the species Pyromaia tuberculata was identified through integrative taxonomy, combining morphological and genetic approaches, which provided a robust and consistent identification of the specimens, recorded for the first time in the east Atlantic.

\section{Materials and Methods}

\subsection{Sampling and Sample Processing}

Several sediment samples were collected between 23 May 2016 and 28 September 2017, using a $0.1 \mathrm{~m}^{2}$ Smith-McIntyre grab in the Tagus estuary, bordering the city of Lisbon in western mainland Portugal (from $38^{\circ} 41.773^{\prime} \mathrm{N}, 9^{\circ} 10.231^{\prime} \mathrm{W}$ to $38^{\circ} 47.245^{\prime} \mathrm{N}, 9^{\circ} 5.244^{\prime}$ W) (Figure 1). The sampling stations were located close to the effluents of wastewater treatment plants of the city of Lisbon. Sediment subsamples were used for total organic matter determination and grain size analysis. The remaining sediment samples were sieved through a $500 \mu \mathrm{m}$ mesh sieve, the specimens were stored in absolute ethanol and then photographed with a digital camera.

\subsection{Sediment Grain Size Analysis}

Grain size analysis was performed by dry sieving, following the procedure described in Gaudêncio et al. [19]. Sediment fractions, expressed as a percentage of total dry weight of each sample, were used to determine the descriptive parameters: median (P50 values) 
and sorting coefficient [20], calculated by the expression $\sqrt{Q 3} / Q 1$, where $Q 1$ and $Q 3$ are the 1st and 3rd quartiles, respectively. Those values, as well as the percentage of fines and gravel according to Folk's classification [21], were used to classify the sediment types according to the Udden/Wentworth scale [22].

\subsection{Total Organic Matter Analysis}

The total organic matter content of the sediment samples was estimated by mass Loss on Ignition (LOI) in a muffle furnace. Pre-weighed, oven-dried $\left(100{ }^{\circ} \mathrm{C}\right)$ and subsequently mashed up samples were ignited at $450^{\circ} \mathrm{C}$ to constant weight. After cooling in a desiccator at room temperature, they were weighed again. The total organic matter content was estimated by the difference between the weight of the oven-dried samples and the weight of the combusted ones.

\subsection{Morphological Analysis}

Morphological identification was carried out under a stereomicroscope Leica MZ12, using dichotomous keys $[2,23,24]$ and descriptions of genus and species $[2,13,24,25]$. Specimens' measurements were obtained with a vernier calliper following Garth [24] and are expressed in millimetres (mm). Specimens' sex was determined by visual examination of the shape of the abdomen. Life stage was identified according to morphometric data and to the comparative description of adult and young specimens [2].

\subsection{Molecular Analysis}

A small piece of tissue (approximately $3 \mathrm{~mm}^{3}$ ) was extracted from each specimen in order to perform molecular analysis. The genetic marker, Cytochrome $c$ oxidase subunit I (COI-5P), was amplified with puRe Taq Ready-To-Go PCR beads (Amersham Biosciences, Little Chalfont, UK) and the primer pair, LoboF1 (5'-KBTCHACAAAYCAYAARGAYATHGG$3^{\prime}$ ) and LoboR1 (5'-TAAACYTCWGGRTGWCCRAARAAYCA-3') [26], using a BioRad thermal cycler. The PCR thermal cycling conditions were as follows: (1) $5^{\prime}$ at $94{ }^{\circ} \mathrm{C}$; (2) 5 cycles: $30^{\prime \prime}$ at $94{ }^{\circ} \mathrm{C}, 1^{\prime} 30^{\prime \prime}$ at $45^{\circ} \mathrm{C}, 1^{\prime}$ at $72{ }^{\circ} \mathrm{C}$; (3) 45 cycles: $30^{\prime \prime}$ at $94^{\circ} \mathrm{C}, 1^{\prime} 30^{\prime \prime}$ at $54^{\circ} \mathrm{C}$, $1^{\prime}$ at $72{ }^{\circ} \mathrm{C}$; (4) $5^{\prime}$ at $72{ }^{\circ} \mathrm{C}$. Each reaction contained $1.5 \mu \mathrm{L}(10 \mu \mathrm{m})$ of each primer, $4 \mu \mathrm{L}$ of DNA template and was completed with sterile milliQ-grade water to a total volume of $25 \mu \mathrm{L}$. PCR products were stained with Greensafe (NZYTech, Lisbon, Portugal) and then separated by electrophoresis in 1.5\% agarose gel in TBE buffer. Amplified products were purified using magnetic beads and subsequently sequenced bidirectionally by StabVida, using the BigDye Terminator 3 kit on an ABI 3730XL DNA analyser (Applied Biosystems ${ }^{\mathrm{TM}}$, Foster City, CA, USA). All information about the specimens was compiled in a data set created in BOLD (Data set DS-PTUBERCU): specimen details, images, taxonomy, collection data and genetic information. GenBank accession numbers for the sequences obtained are included between MZ261721 and MZ261725.

Molecular analysis was performed using MEGA version X [27]. Sequence trace files were analysed and then the sequences were manually aligned. BOLD Identification System tool (BOLD-IDS) [28] and GenBank BLASTn search [29] were used to search for matching sequences. Sequences belonging to the same species, plus other taxonomically related species, were added to the alignment for subsequent analysis. An estimation of evolutionary divergence between sequences was conducted using the Kimura 2-parameter model [30]. The evolutionary history was inferred by using the Maximum Likelihood method and Tamura 3-parameter (T92) model [31]. T92 was indicated to describe the substitution pattern the best, by having the lowest BIC score (Bayesian Information Criterion) in MEGA version X.

\section{Results}

\subsection{Taxonomic Description}

(1) Family Inachoididae Dana, 1851

(2) Subfamily Inachoidinae Dana, 1851

(3) Pyromaia Stimpson, 1871 


\section{(4) Pyromaia tuberculata (Lockington, 1877)}

Diagnosis: Carapace broadly pyriform. Surface granulate and tuberculate with fine pubescence. Granulation more extensive in female. Three median tubercles: one gastric, one cardiac, and one intestinal. Tubercles more prominent in male. Gastric and cardiac tubercles enlarged; intestinal tubercle spiniform. Short spiniform tubercle on the first abdominal segment. Female abdomen broad, rounded. Male abdomen narrow, with lateral borders slightly concave and distal part subtriangular with rounded apex. Rostrum a simple spine. Supraorbital arch with a tubercle (very short in female) at summit; postorbital spine large curving around eye in male. Antero-external spine of basal antennal article incurving in male, not incurving and shorter in female. Male cheliped shorter than pereopods II to IV, and almost the same length as pereopod V. Female cheliped shorter than pereopods II to V, slenderer than in male. Chela subglobular in male, slightly inflated in female. Dactyls long, slightly incurved, unarmed.

Note: intestinal tubercle very short, almost indistinct in specimen Pt3 (male). Cheliped longer than pereopod V in specimen Pt5 (male). Cheliped much shorter than pereopod II, shorter than pereopods III and IV, almost the same length as pereopod V in specimen Pt7 (male).

\subsection{Material Examined}

A total of 6 specimens collected at five stations in the Tagus estuary, Portugal (Figure 1). One male and one ovigerous female are shown in Figure 2. Information about the sampling stations is presented in Table 1.

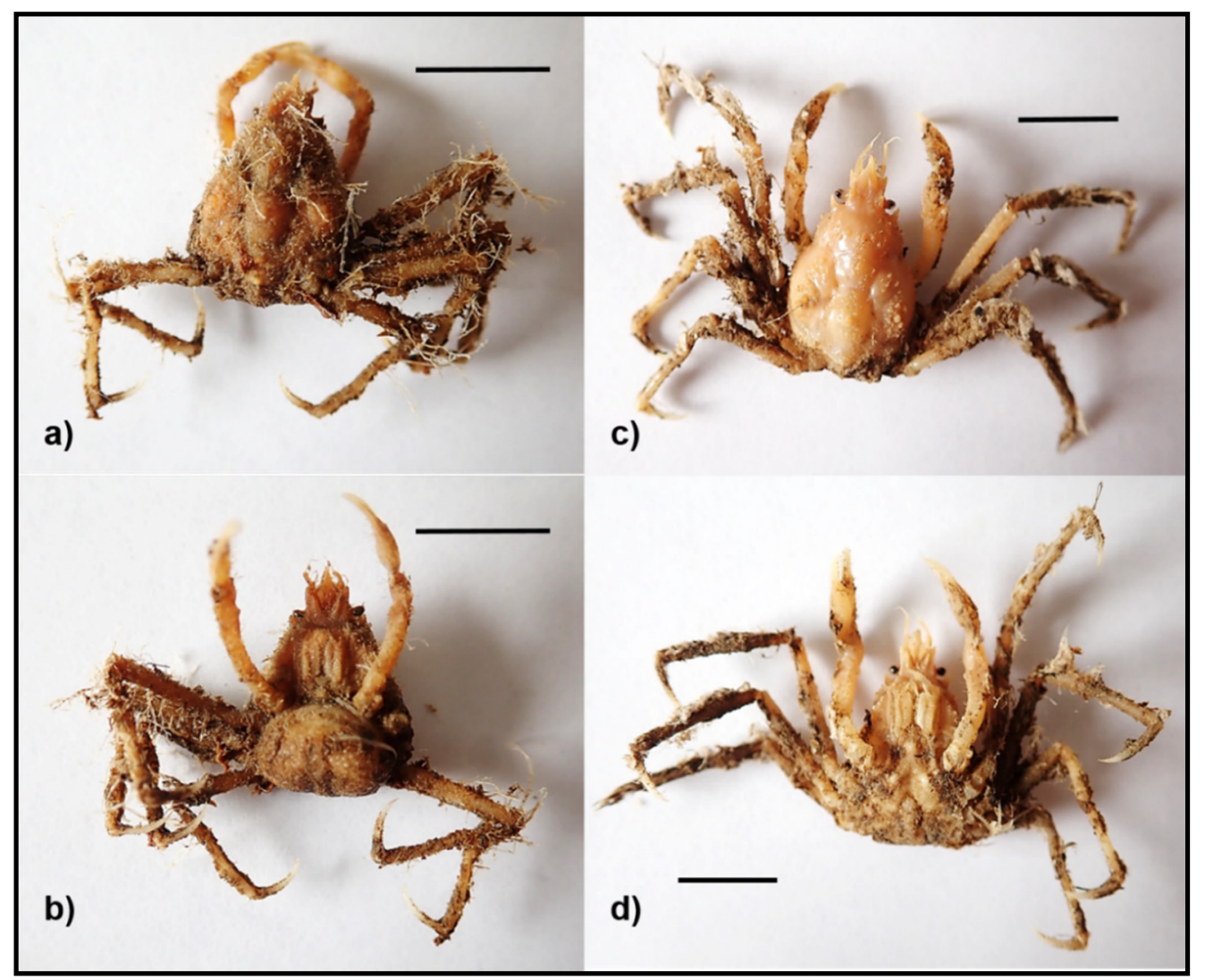

Figure 2. Pyromaia tuberculata collected in the Tagus estuary, Portugal. Female (Pt2) dorsal (a) and ventral (b) views; male (Pt3) dorsal (c) and ventral (d) views. Scale bar represents $10 \mathrm{~mm}$. 
Table 1. Characterisation of the sampling stations of Pyromaia tuberculata in the Tagus estuary, Lisbon.

\begin{tabular}{|c|c|c|c|c|c|}
\hline Station & A8 & T6 & B11 & C9 & T1 \\
\hline WTP & Alcântara & Terreiro do Paço & Beirolas & Chelas & Terreiro do Paço \\
\hline Sampling device & $\begin{array}{l}\text { Smith-McIntyre } \\
\text { grab } 0.1 \mathrm{~m}^{2}\end{array}$ & $\begin{array}{l}\text { Smith-McIntyre } \\
\text { grab } 0.1 \mathrm{~m}^{2}\end{array}$ & $\begin{array}{l}\text { Smith-McIntyre } \\
\text { grab } 0.1 \mathrm{~m}^{2}\end{array}$ & $\begin{array}{l}\text { Smith-McIntyre } \\
\text { grab } 0.1 \mathrm{~m}^{2}\end{array}$ & Beam trawl \\
\hline Date & 28 September 2017 & 27 September 2017 & 10 October 2016 & 12 October 2016 & 23 May 2016 \\
\hline Depth (m) & 19.6 & 16.1 & 6.7 & 14.6 & 18-19 \\
\hline Latitude N & $38^{\circ} 41.773^{\prime}$ & $38^{\circ} 42.277^{\prime}$ & $38^{\circ} 47.245^{\prime}$ & $38^{\circ} 43.390^{\prime}$ & $\begin{array}{c}38^{\circ} 42.421^{\prime} \text { to } \\
38^{\circ} 42.315^{\prime}\end{array}$ \\
\hline Longitude W & $9^{\circ} 10.231^{\prime}$ & $9^{\circ} 7.962^{\prime}$ & $9^{\circ} 5.244^{\prime}$ & $9^{\circ} 6.251^{\prime}$ & $\begin{array}{c}9^{\circ} 7.612^{\prime} \\
\text { to } 9^{\circ} 7.887^{\prime}\end{array}$ \\
\hline Surface salinity & 34.69 & 33.79 & 15.30 & 30.40 & NA \\
\hline Gravel fraction (\%) ${ }^{a}$ & 57.9 & 9.3 & 4.1 & 1.9 & $4.6-7.6$ \\
\hline Sand fraction $(\%){ }^{b}$ & 34.5 & 66.6 & 95.8 & 37.3 & $76.5-69.5$ \\
\hline Fine fraction $(\%)^{c}$ & 7.6 & 24.1 & 0 & 60.8 & $18.9-22.9$ \\
\hline Median $(\mu \mathrm{m})$ & 2198 & 210 & 294 & - & $270-211$ \\
\hline So & 2 & - & 1.3 & - & $1.5-1.7$ \\
\hline TOM (\%) & 3.6 & 3.6 & 2.7 & 4.7 & $1.6-2.9$ \\
\hline Solids (\%) & 74 & 57 & 72 & 63 & $62-74$ \\
\hline
\end{tabular}

WTP: Wastewater treatment plant. ${ }^{a}$ Particle size $8000-2000 \mu \mathrm{m} .{ }^{\mathrm{b}}$ Particle size $2000-63 \mu \mathrm{m} .{ }^{\mathrm{c}}$ Particle size $<63 \mu \mathrm{m}$. So: Sorting coefficient. TOM: Total Organic Matter.

\subsection{Biometry}

Specimens measurements, as well as gender and life stage are shown in Table 2.

Table 2. Sex, life stage and measurements ( $\mathrm{mm})$, of Pyromaia tuberculata specimens collected in the Tagus estuary, Lisbon.

\begin{tabular}{ccccccc}
\hline Specimen & Pt1 & Pt2 & Pt3 & Pt4 & Pt5 & Pt7 \\
\hline $\begin{array}{c}\text { Sex } \\
\text { Life Stage }\end{array}$ & Male & Female & Male & Male & Male & Male \\
Adult & Adult & Adult & Adult & Adult & Adult \\
$\begin{array}{c}\text { Length of carapace, including } \\
\text { rostrum }\end{array}$ & 15.0 & 16.0 & 17.0 & 19.0 & 20.0 & 13.0 \\
Length of rostrum & 4.5 & 4.0 & 4.0 & 6.0 & 4.0 & 4.0 \\
Width of rostrum & 3.5 & 3.0 & 4.0 & 4.0 & 4.0 & 4.0 \\
Length of carapace without & 10.5 & 12.0 & 13.0 & 13.0 & 16.0 & 11.0 \\
$\quad$ rostrum & 9.2 & 10.0 & 12.0 & 15.0 & 16.0 & 9.0 \\
Width of carapace & 16.5 & 15.0 & 20.0 & 26.0 & 28.0 & 14.0 \\
Length of cheliped & 7.01 & 6.0 & 9.0 & 13.0 & 14.0 & 7.0 \\
Length of chela & 4.02 & 4.0 & 5.0 & 7.0 & 8.0 & 4.0 \\
Length of dactyl & 28.0 & 25.0 & 31.0 & 40.0 & 41.0 & 25.0 \\
Length of first walking leg & 26.0 & 24.0 & 29.0 & 35.0 & 36.0 & 23.0 \\
Length of second walking leg & 24.0 & 23.0 & 27.0 & 31.0 & 33.0 & 21.0 \\
Length of third walking leg & 21.0 & 20.0 & 26.0 & 30.0 & 30.0 & 19.0 \\
Length of fourth walking leg & & & &
\end{tabular}

${ }^{1}$ Measure taken on the external margin (fixed finger). ${ }^{2}$ Measure taken on the inner margin (mobile finger).

\subsection{Distribution and Ecology}

P. tuberculata is native to the north-eastern Pacific Ocean [2] and already established in distant regions in the Pacific Ocean and southwest Atlantic. In this study we present a new record of the species in the northeast Atlantic, Portugal, being the first one in Europe (Figure 1). In its native region, the species lives under rocks, among sponges and seaweed on wharf piles, on sand and mud, from the intertidal zone down to $650 \mathrm{~m}$ [1]. However, out of its native range it is found mainly in organically polluted and large shallow bays from the intertidal zone down to $80 \mathrm{~m}$ [5,32], close to populous urban areas and ports with dense vessel traffic, as, for example, in Tokyo (Japan) and in Rio de Janeiro (Brazil). In the Tagus estuary, it was found from 7 to $20 \mathrm{~m}$ depth in sediments with different physico-chemical 
characteristics, but always close to the effluents of wastewater treatment plants of the city of Lisbon. The total organic matter of the sediments ranged from 2 to $5 \%$, and sediment grain size varied from sandy gravel to slightly gravely sandy mud (Table 1 ).

\subsection{Genetic Analysis}

The new COI-5P sequences, with $658 \mathrm{bp}$, obtained from all specimens found in the Tagus estuary were identical; no genetic divergence was observed. The same pattern is found when comparing our sequences to all available COI-5P sequences from Argentina, Brazil, California (USA), and Japan. A phylogenetic tree is represented in Figure 3.

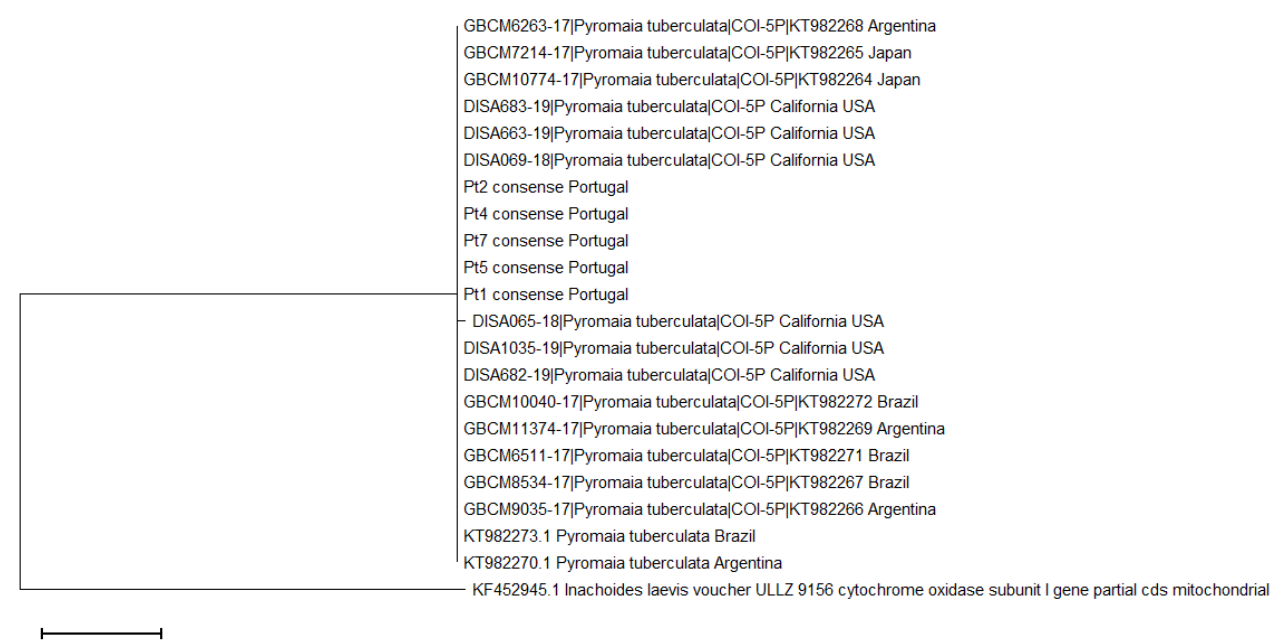

Figure 3. Maximum likelihood tree, generated from COI-5P sequences of Pyromaia tuberculata from Argentina, Brazil, California (USA), Japan, and Portugal. 1000 bootstrap replications were applied. Data coverage of the node is $82 \%$. Scale bar represents 0.02 substitutions per site.

\section{Discussion}

The first record of $P$. tuberculata out of its native region was in Japan before 1970 [3]. Afterwards it was identified in Oere Point, New Zealand and Cockburn Sound, Australia, in 1978 ([9,10], respectively), and Jukbyeon, Korea, in 1982 [33]. Later, in 1988, the species was collected in the southwest Atlantic Ocean, in Paraná, Brazil [4] and recently, in 2000, in Uruguay and in Samboronbón Bay and Mar del Plata, Argentina [13]. In the meantime, the species was also expanding its distribution over the Pacific Ocean, with records in Japan (Tokyo Bay, [6,7]), Australia (e.g., in Port Phillip Bay [11], east of Newcastle [12]) and Korea (Gijang, Busan, [8]). Not only has the species been expanding its distribution around the Pacific and southwest Atlantic, but it has successfully adapted to different environments, being quite abundant in some locations [5].

Although this is the first record of P. tuberculata in the northeast Atlantic, it is not likely that the species is newly arrived. It is probable that a population is already established in the Tagus estuary, since several adult specimens were collected there over 16 months (between May 2016 and September 2017), including one ovigerous female. Furota et al. [7] observed that females reach maturity within 6 months after settlement, and the life cycle of the species is short, completing at least two reproduction events per year. However, further investigation is needed in order to confirm its establishment in Portuguese waters. Since the pelagic larval stages of the species take approximately 17.5 days (two zoeal stages and one megalopa) before settlement [11], its long-distance introduction pathway is likely to be shipping, and ballast water the vector of introduction in Europe, as reported by other authors for the South Pacific and West Atlantic (e.g., [1,6]).

The COI-5P barcode sequences of $P$. tuberculata generated in this study were compared to those available in public databases and no divergences between them were found, probably because the species dispersion is relatively recent. For this reason, haplotype network analysis could not be performed in order to identify the population genetic 
structure to unveil the colonization process and potential population of origin, as several studies have shown [34,35]. The availability of these sequences in public databases will help to promptly detect new introductions through plankton communities, since ballast water is a primary transport vector of species with a planktonic phase [36]. The use of a high-throughput sequencing metabarcoding approach using plankton communities, environmental DNA, or sediment samples (e.g., $[37,38]$ ), has demonstrated to be reliable for application to non-indigenous species.

There are no adverse effects associated with the species so far [1]. Despite being widely established outside its native range, $P$. tuberculata continues to expand. Its short life cycle, resistance to quasi-anoxic conditions, and tolerance to a wide range of temperatures [7] give the species the ability to establish in remote locations and to rapidly colonise local habitats. Even so, it would indeed be desirable that its inclusion be considered in European monitoring programmes of non-indigenous species, as a contribution to improve the scientific knowledge required for the assessment of descriptor 2 (non-indigenous species) under the European Marine Strategy Framework Directive, namely tracking and minimising new introductions.

Author Contributions: All authors contributed to the study conception and design. M.T.-G. and M.J.G. collected the organisms and data and performed morphological analysis, as well as grain size and total organic matter analyses. J.L.-A. performed molecular analysis and analysed the data. J.L.-A. led the writing of the manuscript. All authors contributed critically to the revision of the submitted manuscript. All authors have read and agreed to the published version of the manuscript.

Funding: This study was supported by the project ProtectInvad, funded by the European Union and the Portuguese Government under the Mar2020 Programme. Other supports were provided by the Marine and Environmental Sciences Centre (MARE) which is financed by national funds from FCT / MCTES (UIDB/04292/2020) and by the Interdisciplinary Centre of Marine and Environmental Research (CIIMAR), reference UIDB/04423/2020 and UIDP/04423/2020.

Institutional Review Board Statement: Not applicable.

Informed Consent Statement: Not applicable.

Data Availability Statement: All specimens were deposited in the National Museum of Natural History and Science in Lisbon, Portugal. GenBank accession numbers for the sequences obtained in this study are included between MZ261721 and MZ261725.

Acknowledgments: The authors are grateful to António Manuel Pereira (IPMA) for helping with sediment and organisms sampling and sorting, as well as laboratory procedures for sediment physicochemical analyses.

Conflicts of Interest: The authors declare no conflict of interest.

\section{References}

1. Brockerhoff, A.M.; McLay, C.L. Human-Mediated Spread of Alien Crabs. In In the Wrong Place-Alien Marine Crustaceans: Distribution, Biology and Impacts; Galil, B., Clark, P.F., Carlton, J.T., Eds.; Springer Science: Frankfurt, Germany, 2011 ; pp. 27-106. [CrossRef]

2. Rathbun, M.J. The spider crabs of America. Bull. US Nat. Mus. 1925, 129, 1-613. [CrossRef]

3. Sakai, T. Crabs of Japan and the Adjacent Seas; Kodansha: Tokyo, Japan, 1976.

4. Melo, G.A.S.; Veloso, V.G.; Oliveira, M.C. A fauna de Brachyura (Crustacea, Decapoda) do litoral do estado de Paraná. Lista preliminar. Nerítica 1989, 4, 1-31. (In Portuguese)

5. Tavares, M.; Mendonça, J.B., Jr. Introdução de crustáceos decápodes exóticos no Brasil: Uma roleta ecológica. In Água de Lastro e Bioinvasão; InterCiência: Rio de Janeiro, Brazil, 2004; pp. 59-76. (In Portuguese)

6. Furota, T. Life cycle studies on the introduced spider crab Pyromaia tuberculata (Lockington) (Brachyura: Majidae). I. Egg and larval stages. J. Crustacean Biol. 1996, 16, 71-76. [CrossRef]

7. Furota, T. Life cycle studies on the introduced spider crab Pyromaia tuberculata (Lockington) (Brachyura: Majidae). II. Crab stage and reproduction. J. Crustacean Biol. 1996, 16, 77-91. [CrossRef]

8. Oh, S.M.; Ko, H.S. Complete larval development of Pyromaia tuberculata (Crustacea: Decapoda: Majoidea: Inachoididae). Anim. Cells Syst. 2010, 14, 129-136. [CrossRef] 
9. Morgan, G.J. An introduced eastern Pacific majid crab from Cockburn Sound, southwestern Australia. Crustaceana 1990, 58, 316-317. [CrossRef]

10. Webber, W.R.; Wear, R.G. Life history studies on New Zealand Brachyura, 5. Larvae of family Majidae. N. Z. J. Mar. Freshw. Res. 1981, 15, 331-383. [CrossRef]

11. Poore, G.C.B.; Storey, M. Soft sediment Crustacea of Port Phillip Bay. In Marine Biological Invasions of Port Phillip Bay, Victoria. Centre for Research on Introduced Marine Pests Technical Report 20; Hewitt, C., Campbell, M.L., Thresher, R.E., Martin, R.B., Eds.; CSIRO Marine Research: Hobart, Australia, 1999; pp. 150-170.

12. Ahyong, S.T. Range extension of two invasive crab species in eastern Australia: Carcinus maenas (Linnaeus) and Pyromaia tuberculata (Lockington). Mar. Pollut. Bull. 2005, 50, 460-462. [CrossRef] [PubMed]

13. Schejter, L.; Spivak, E.D.; Luppi, T. Presence of Pyromaia tuberculata (Lockington, 1877) adults and larvae in the Argentine continental shelf (Crustacea: Decapoda: Majoidea). Proc. Biol. Soc. Wash. 2002, 115, 605-610.

14. Fransozo, A.; Sousa, A.N.D.; Barros Rodrigues, G.F.; Telles, J.N.; Fransozo, V.; Negreiros-Fransozo, M.L. Decapod crustaceans captured along with the sea-bob shrimp fisheries on non-consolidated sublitoral from Northern coast of São Paulo, Brazil. B. Inst. Pesca. 2016, 42, 369-386. (In Portuguese with English Abstract) [CrossRef]

15. Costa, F.O.; DeWaard, J.R.; Boutillier, J.; Ratnasingham, S.; Dooh, R.T.; Hajibabaei, M.; Hebert, P.D. Biological identifications through DNA barcodes: The case of the Crustacea. Can. J. Fish. Aquat. Sci. 2007, 64, 272-295. [CrossRef]

16. Lobo, J.; Ferreira, M.S.; Antunes, I.C.; Teixeira, M.A.L.; Borges, L.M.; Sousa, R.; Gomes, P.A.; Costa, M.H.; Cunha, M.R.; Costa, F.O. Contrasting morphological and DNA barcode-suggested species boundaries among shallow-water amphipod fauna from the southern European Atlantic coast. Genome 2016, 60, 147-157. [CrossRef] [PubMed]

17. Lobo, J.; Tuaty-Guerra, M. A new deep-sea Cirripedia of the genus Heteralepas from the northeastern Atlantic. Eur. J. Taxon. 2017, 385. [CrossRef]

18. Bartilotti, C.; Salabert, J.; Dos Santos, A. Complete larval development of Thor amboinensis (De Man, 1888) Decapoda: Thoridae) described from laboratory-reared material and identified by DNA barcoding. Zootaxa 2016, 4066, 399-420. [CrossRef]

19. Gaudêncio, M.J.; Guerra, M.T.; Glémarec, M. 1991 Recherches biosédimentaires sur la zone maritime de l'estuaire du Tage, Portugal: Données préliminaire. In Estuaries and Coasts: Spatial and Temporal Intercomparisons; Elliott, M., Ducrotoy, J.-P., Eds.; Olsen and Olsen: Fredensborg, Denmark, 1991; pp. 11-16. (In French)

20. Trask, P.D. Mechanical analyses of sediments by centrifuge. Econ. Geol. 1930, 25, 581-599. [CrossRef]

21. Folk, R.L. The distinction between grain size and mineral composition in sedimentary rock nomenclature. J. Geol. 1954, 62, 344-359. [CrossRef]

22. Wentworth, C.K. A scale of grade and class terms for clastic sediments. J. Geol. 1922, 30, 377-392. [CrossRef]

23. Lemaitre, R.; Campos, N.H.; Bermúdez, A. A new species of Pyromaia from the Caribbean Sea, with a redescription of P. propinqua Chace, 1940 (Decapoda: Brachyura: Majoidea: Inachoididae). J. Crustac. Biol. 2001, 21, 760-773. [CrossRef]

24. Garth, J.S. Brachyura of the Pacific coast of America. Oxyrhyncha. Allan Hancock Pac. Exped. 1958, 21, 1-499.

25. Hendrickx, M.E. The stomatopod and decapod crustaceans collected during the GUAYTEC 11 Cruise in the Central Gulf of California, México, with the description of a new species of Plesionika Bate (Caridea: Pandalidae). Rev. Biol. Trop. 1990, $38,35-53$.

26. Lobo, J.; Costa, P.M.; Teixeira, M.A.L.; Ferreira, M.S.; Costa, M.H.; Costa, F.O. Enhanced primers for amplification of DNA barcodes from a broad range of marine metazoans. BMC Ecol. 2013, 13, 34. [CrossRef]

27. Kumar, S.; Stecher, G.; Li, M.; Knyaz, C.; Tamura, K. MEGA X: Molecular Evolutionary Genetics Analysis across Computing Platforms. Mol. Biol. Evol. 2018, 35, 1547-1549. [CrossRef] [PubMed]

28. Ratnasingham, S.; Hebert, P.D.N. BOLD: The Barcode of Life Data System (http://www.barcodinglife.org). Mol. Ecol. Resour. 2007, 7, 355-364. [CrossRef]

29. Altschul, S.F.; Gish, W.; Miller, W.; Myers, E.W.; Lipman, D.J. Basic local alignment search tool. J. Mol. Biol. 1990, 215, 403-410. [CrossRef]

30. Kimura, M. A simple method for estimating evolutionary rate of base substitutions through comparative studies of nucleotide sequences. J. Mol. Evol. 1980, 16, 111-120. [CrossRef]

31. Tamura, K. Estimation of the number of nucleotide substitutions when there are strong transition-transversion and $\mathrm{G}+\mathrm{C}$-content biases. Mol. Biol. Evol. 1992, 9, 678-687. [CrossRef] [PubMed]

32. Furota, T.; Furuse, K. Distribution of the introduced spider crab, Pyromaia tuberculata, along the coast of Japan. Benthos Res. 1988, 33, 75-78. [CrossRef]

33. Kim, H.S. Systematic studies on crustaceans of Korea, 1. Decapods. Proc. Coll. Nat. Sci. Seoul Natl. Univ. 1985, $10,63-94$.

34. Torkkola, J.; Riginos, C.; Liggins, L. Regional patterns of mtDNA diversity in Styela plicata, an invasive ascidian, from Australian and New Zealand marinas. Mar. Freshw. Res. 2013, 64, 139-145. [CrossRef]

35. Pineda, M.C.; Turon, X.; Pérez-Portela, R.; López-Legentil, S. Stable populations in unstable habitats: Temporal genetic structure of the introduced ascidian Styela plicata in North Carolina. Mar. Biol. 2016, 163, 59. [CrossRef]

36. Carlton, J.T.; Geller, J.B. Ecological roulette: The global transport of nonindigenous marine organisms. Science 1993, 261, 78-82. [CrossRef] [PubMed] 
37. Zaiko, A.; Samuiloviene, A.; Ardura, A.; Garcia-Vazquez, E. Metabarcoding approach for nonindigenous species surveillance in marine coastal waters. Mar. Pollut. Bull. 2015, 100, 53-59. [CrossRef] [PubMed]

38. Rey, A.; Basurko, O.C.; Rodriguez-Ezpeleta, N. Considerations for metabarcoding-based port biological baseline surveys aimed at marine nonindigenous species monitoring and risk assessments. Ecol. Evol. 2020, 10, 2452-2465. [CrossRef] 